\title{
Õpetajate õppimiskogemused neoliberaalsete haridusmuutuste taustal
}

\author{
Inge Timoštšuk ${ }^{\text {al }}$, Aino Ugaste ${ }^{\mathrm{a}}$, Kristi Mets-Alunurma ${ }^{\mathrm{a}}$ \\ ${ }^{a}$ Tallinna Ülikooli haridusteaduste instituut
}

\begin{abstract}
Annotatsioon
Õpetajatöö on stressirohke ja pingete tõttu võidakse ametist loobuda. Ühed pingete põhjused on kiired muutused haridussüsteemis. Uuenevate olude ja ootustega toimetulek eeldab õpetajalt õppimist ja sotsiaalse keskkonna tuge. Et mõista, kuidas õpetajate õppimist muutuste taustal toetada, on meie eesmärk kirjeldada, kuidas kajastuvad neoliberaalsed haridusmuutused õpetajate õpikogemustes, ning analüüsida, millised õpikogemused on õpetajatele tähenduslikumad. 33 õpetajaga tehtud intervjuudest selgub, et õpetajad tajuvad positiivsete majanduslike muutuste kõrval vastuolu liberaalsete väärtuste (nt õppija individuaalsuse arvestamise) ning haridustulemuslikkusele, sh tulemuste mõõdetavusele orienteerituse vahel. Selle vastuoluga toimetulekuks saadakse tuge lähematelt kolleegidelt, kuid vajatakse ka kõrgetasemelist täiendõpet ja õpetaja kui tipp-professionaali tunnustamist ühiskonnas.
\end{abstract}

Võtmesõnad: haridusmuutused, neoliberalism, sotsiaalne õppimine, õpetaja

\section{Sissejuhatus}

Õpetamine ning hariduskontekst muutuvad pidevalt. Britzman (2007) on niisugust paratamatust nimetanud õpetaja töö ebakindluseks (ingl uncertainty of teaching), mille taga on nii paratamatu õpetamisolukordade variatiivsus kui ka hariduspoliitilised muutused. Selliste muutuste silmapaistvaks näiteks on Eesti taasiseseisvumisega saavutatud demokraatlik ühiskonnakorraldus (vrd nt Kitsing et al., 2016; Sarv, 1999). Sel ajal hakkasid haridust mõjutama turumajanduslikud printsiibid ning liberaalne maailmavaade. Samasuunalised

Haridusteaduste Instituut, Tallinna Ülikool, Narva mnt 25, 10120 Tallinn;

inge.timostsuk@tlu.ee 
muutused hariduses jätkuvad, kuid need pole enam nii murrangulised ja toimuvad samm-sammult.

Eesti on viimased aastakümned olnud globaalsete neoliberaalsete trendide mõjuväljas (Ruus \& Timoštšuk, 2014). Ideoloogiliste ja majanduslike trendide mõju avaldub saavutusele orienteerituses ning haridustulemuste võrreldavuse soovis (Apple, 2006; Green, 1997; Olssen, 2004). Muu hulgas oodatakse, et õpetajad suudaksid õppijaid senisest paremate tulemusteni viia. Eesti õpilased ongi saavutanud väga silmapaistvaid tulemusi ja need on aastatega üha paranenud. Näiteks on rahvusvaheliste võrdlusuuringute põhjal meie põhikooli 15aastaste õpilaste tulemused loodusteadustes, matemaatikas ja lugemises ning koostöised probleemilahendusoskused Euroopa tipus ja maailmas kõrgel kohal (OECD, 2016). Samas on turumajanduslikes ühiskondades võetud üha selgem suund hariduskulude kärpimisele (Bates \& Townsend, 2007; Cochran-Smith, 2006; Kostogriz, 2007). Eestis räägitakse pigem kulude optimeerimisest - raha oluliselt ei vähene, kuid seda jagatakse ümber. Näiteks kujundatakse ümber õpetaja töökoormust ja korrastatakse koolivõrku.

Sama moodi nagu teistes riikides, on ka Eestis õpetaja hariduspoliitika ja sotsiaalsete muutuste mõjuväljas (vrd Goodson, 2014). Samas on teada, et soov saavutada väiksemate vahenditega senisest parem tulemus tekitab õpetajates trotsi ning väliste ootuste ja enese kutsealaste arusaamade vastuolu põhjustab pingeid (Bullough \& Gitlin, 2001; Hargreaves, 2006). Ka Eesti õpetajate rahulolematus oma ametis on suuresti seotud kooliväliste, endast ja kolleegidest vähe sõltuvate asjaoludega, nagu töötasu, õpetajakutse vähene avalik tunnustamine ühiskonnas ja meedias (OECD, 2013). Ainult 13,7\% õpetajatest tajub, et ühiskond väärtustab nende tööd (samas). Samade andmete põhjal on valdav osa (90\%) õpetajaid oma tööga rahul - tegemist on olulise vastuoluga. Tajutakse rahulolu töö sisu ja tulemustega, kuid tagasiside, mida saadakse, ja ootused, mida õpetajale hariduse huvirühmad esitavad, tekitavad ebameeldivust. Paraku on teada, et kui õpetaja tööga seotud pinged kasvavad liiga suureks ja neid ei osata enam ületada, loobutakse õpetajaameti valikust või püsitakse ametis väga lühikest aega (Day, 2004; Day, Elliot, \& Kington, 2005; Flores \& Day, 2006; Stokking, Leenders, De Jong, \& Van Tartwijk, 2003). Sellist perspektiivi peaks hästi haritud ja noorte õpetajate puuduse ning õpetajaskonna süveneva vananemise taustal (OECD, 2008, 2013) kindlasti vältima.

Toimetulek nii, et ametis läbi ei põleta või sellest ei loobuta, eeldab õpetajalt pidevat õppimist ja sotsiaalse keskkonna tuge. Et paremini mõista, kuidas õpetajate õppimist muutuste taustal toetada, on meie eesmärk 1) kirjeldada, kuidas kajastuvad neoliberaalsed haridusmuutused õpetajate õpikogemustes; 2) analüüsida, millised õpikogemused on õpetajatele tähenduslikumad. 


\section{Teoreetilised lähtekohad}

\section{Haridusmuutuste sisu ja mõju}

Hariduse arengu suunamist ja mõjutamist riigiasutuste või ühiskonna huvirühmade poolt nimetatakse hariduspoliitikaks (Mikser \& Heidmets, 2013). Hariduspoliitika vahendid on strateegiline arengu kavandamine, ressursside jaotamine, juhtimismudelite kujundamine, personali valik ning avaliku arvamuse kujundamine haridusküsimustes (samas).

Eesti hariduspoliitika kõige silmapaistvam muutus on olnud 1980ndate lõpust alanud postkommunistlik transformatsioon ehk üleminek sotsialistlikult formatsioonilt kapitalistlikule (Männiste, 2014; Sarv, 1999). Totalitaarsed väärtused, tegevustavad ja normid asendusid siis liberaalsetega. Liberaalsust iseloomustab usk inimmõistusesse, inimese enesemääratlus- ja õppimisvõimesse ning ratsionaalsuse, humaansuse, moraalsuse, subjektsuse, emantsipatsiooni ja individuaalsuse väärtustamine (Autio, Kuurme, \& Mikser, 2013). Need mõisted on olnud senini keskseks arutlusobjektiks, kui räägitakse demokraatiast, aga ka sotsiaalsetest normidest või tavadest ning tervisest ja heaolust (vrd Wringe, 2010). Nende ideede toel on arendatud riiklikke õppekavu ja hariduskorralduslikke dokumente. Samas on liberaalne Eesti nüüdseks paigutunud globaalsesse konteksti. Globaliseerumist tingib suurte rahvusvaheliste organisatsioonide (Euroopa Liidu, Majanduskoostöö ja Arengu Organisatsiooni, Maailma Kaubandusorganisatsiooni) roll riikidevahelises suhtluses (Mikser \& Heidmets, 2013). Meie riik on praegu avatud nii kapitali kui ka inimeste liikumisele ning riikideülesed majandushuvid määravad Eesti tegevuse ja poliitika. Haridusvaldkonnas on sellekohaseks silmapaistvaks näiteks OECD rahvusvahelistes võrdlusuuringutes osalemine ning õppesisu ja -praktikate kohanemine sellega.

Globaalsed trendid kajastuvad ka haridusstrateegilistes dokumentides. Eestis kujundab haridusvaldkonna tähtsaimaid muudatusi Eesti elukestva õppe strateegia 2014-2020. Elukestva õppe strateegia eesmärgid ja meetmed toetavad konkurentsivõime kava „Eesti 2020“, Eesti säästva arengu riikliku strateegia „Säästev Eesti 21“ ning Eesti julgeolekupoliitika alaste haridusvaldkonnaga seotud eesmärkide täitmist (Eesti elukestva õppe strateegia, 2014). Nende strateegiate ning eesmärgiseadete taga on neoliberaalsed haridustrendid. Näiteks selleks, et inimeste töövõimet paremini toetada ja ära kasutada, tuleks neile õpetada õpioskuseid ja kujundada neis valmisolek pidevõppeks ning infoja kommunikatsioonitehnoloogia kasutamiseks (vrd Grubb \& Lazerson, 2006; OECD, 2013; Rizvi \& Lingard, 2006). Kuna tehnoloogia areng on kiire ja see mõjutab nii õppesisu kui ka õpetaja ja õppijate suhtlemist, siis on just see valdkond haridusuuenduse erilises fookuses (vt nt Eesti elukestva õppe strateegia, 
2014). Tehnoloogia arengule lisandub teadmiste pidev juurdekasv ning seetõttu on oskus tulla toime üha uute teadmistega edukuse pragmaatiline eeldus.

Eeltoodut arvesse võttes kerkib eriliselt esile vajadus arvestada kõikide õppijate võimeid ja erinevusi, et viia need maksimumini. Nii on ka erivajadustega õppijate kaasamise temaatika üha suurema tähelepanu all. Paraku on ühiskonnas toimunud nihe hariduslike erivajadustega õpilaste toetamiselt sellele, et nad saaksid koostöös teistega ühiskonnas üha tulemuslikumalt hakkama (Apple, 2006). See on muutnud õpetaja töö aina keerukamaks.

Niisiis on klassikalise liberalismi ideid praeguseks edasi arendatud ja jõutud neoliberalismi ajajärku, mille tunnus on globaliseerumisest tulenev turumajanduse rolli esiletõstmine inimese vabaduste ja võimaluste ees. Kui klassikaline liberalism nägi väärtusena inimese vabadust, sõltumata riigist ja selle majandusest, siis neoliberaalsel ideoloogial on kalduvus kasutada riiki selleks, et aktiivselt kujundada isiksusi, kes tagavad riigi majanduse toimimise (McGregor, 2009; Olssen, 2004).

Hariduses väljenduvad neoliberaalsed ideed peamiselt tööturule orienteerituses ja haridustulemuste pidevas võrdlemises nii riigi sees kui ka riikide vahel (Apple, 2006). Nende eesmärkide täitmiseks rakendatakse standardiseerivaid reforme, näiteks õpetaja kutsestandardi kehtestamine Eestis 2005. aastal. Samas on need standardid (sh riiklik õppekava) säilitanud liberaalsed ja õppijakesksed väärtused, nagu iga õppija vajaduste arvestamise ning võrdsete võimaluste tagamise vajalikkus (Põhikooli ja gümnaasiumi ..., 2007). Seega on siin vastuolu, mille ületamisega õpetajad oma igapäevatöös kokku puutuvad. Selle vastuolu näiteks võib tuua ühe praktilise probleemi: kas selleks, et tasemetöös saavutataks maksimaalne tulemus, peaks õpetaja õpilasi eraldi treenima või oleks pigem oluline luua kõiki õppijate vajadusi maksimaalselt arvestav õpikeskkond? Sarnaseid vastuolusid võib Eesti haridusreformides leida veel teisigi.

Tasakaalu saavutamine mõneti vastandlike eesmärkide vahel on jäänud õpetajate kanda. Paraku on Eestis reformid kaasa toonud õpetajaskonna diferentseerumise, sh erineva professionaalsuse kujunemise (Lepik, Loogma, \& Talts, 2013). Professionaalidel saab muu hulgas vahet teha selle järgi, kuidas nad reageerivad muutustele, nt entusiastlik omaksvõtt, kohandumine või muutuste ignoreerimine (samas). Siiski on nii tööturu vajadused kui ka nendest vajadustest tulenevad standardid avatud ja demokraatlikes ühiskondades paratamatult pidevas arengus ja muutumises (vrd Britzman, 2007). Greeni (1997) väitel on need muutused tingitud põhiliselt kahest asjaolust. Esimene tegur on kultuuride ja nende tegevuspiiride muutumine: kultuurinormide ja väärtuste edasikandmine on mitmekesisuse tingimustes üha keerukam ning seetõttu kerkib hariduses päevakorda küsimus, kuidas uuenevates oludes ümber mõtestada riikluse ja rahvuse teemad. Teine muutusi tingiv aspekt on 
individuaalse soorituse kujunemine üha olulisemaks ja sotsiaalsete väärtuste (teiste austamise, koostöö väärtustamise) jäämine tagaplaanile.

Õpetajatelt eeldatakse aktiivsust neoliberaalsete haridusmuutustega toimetulekul ning oma professionaalsuse ja õppimise ümbermõtestamist nende muutuste taustal (vt nt Furlong, Barton, Whiting, \& Whitty, 2000; Goodson, 2014). See on ka üks neoliberaalsuse üldisematest trendidest - vastutus toimetuleku eest nihkub riigilt või ühiskonnalt üksikindiviidile, praegusel juhul õpetajale (Apple, 2006). Toimetulekule lisab keerukust asjaolu, et õpetajat mõjutavad kolleegide tegevused ja uskumused. Nii ei saa õpetaja õppimist käsitleda teda ümbritsevast tegevuskogukonnast eraldi.

\section{Õpetaja sotsiaalne õppimine haridusmuutustega toimetulekul}

Muutustega toimetulek eeldab õpetajalt pidevat õppimist. Õpetajatöö üha suurem sõltumine majanduslikest ja poliitilistest oludest ning kultuurikeskkonnast (Coldron \& Smith, 1999; Darling-Hammond, 1990; Day, 2005; Lauriala, 1997; Luukkainen, 2000; Robson, 2006; Ruus, 2006, 2010) tingib uue vaatenurga õpetajaõpingutele: professionaalset arengut on põhjust käsitleda tihedas seoses sotsiaalse kontekstiga (Borko, Jacobs, \& Koellner, 2010) ning kirjeldada sotsiaalse õppimisena (Timoštšuk, 2011; Timoštšuk \& Ugaste, 2010). Õpetaja õpib tööga seotud olukordades teistelt, sh kolleegidelt, ja koostöös teistega, sh õpilastega. Õpetaja õppimist reaalsetes oludes ja kutsealases tegevuskogukonnas aitab mõtestada Wengeri õpikäsitus. Wengeri $(1998,2009)$ järgi hõlmab sotsiaalne õppimine ühtaegu nelja dimensiooni:

1) õppimine kui tegemine ja praktika - viis kõnelda ühisest ajaloolisest ja sotsiaalsest pärimusest, ühistest eesmärkidest ja tegevusmustritest;

2) õppimine kui kokkukuuluvus kogukonnaga ja kogukond - viis kõnelda sotsiaalsetest suhetest; meie tegevus on tähenduslik ja pingutust vääriv ning meie osalus selles asjatundlik;

3) õppimine kui identiteedi kujunemine - viis kõnelda sellest, kuidas õppimine on teinud meist selle, kes me oleme;

4) õppimine kui kogemus ja tähendus - viis kõnelda oma elust kui tähenduslikust kogemusest.

Wengeri õpikäsituse kesksed mõisted - kogukond, praktiline tegevus, tähendus ja identiteet - on õpetajahariduse puhul üha enam fookuses. Näiteks on Trent (2010) rõhutanud õpetajate kogukonda kuuluvuse olulisust õpetajaks õppimisel. Õpetajate kogukonnana käsitatakse seejuures inimesi, keda iseloomustab ühine eesmärk, tähelepanu koondamine õpilase õppimisele, koostööle ja arutelule õpetamisest ning jagatud kogemuste väärtustamine (Imants, 2003; Newman, Marks, \& Gamoran, 1996). Praktilist õpetamistegevust 
analüüsitakse rakendatud kutseoskustena (meie uurimuses õpetaja kutsestandardist $(2005,2013)$ lähtudes). Tähendusena mõistetakse äratuntud, edasiarendatud ja väljendatud teadmist praktilisest õpetamistegevusest (Loughran, 2002). Õppijale tähenduslikud praktilised tegevused pakuvad kogemusi, mis toetavad õpetajaks kujunemist. Õpetaja identiteedina mõistetakse inimese teadmist endast õpetamisega seotud olukordades ja suhetes ning identiteet ilmneb inimese praktilises kutsetegevuses, kuuluvustundes ja õpikogemuses (Timoštšuk, 2011).

Autorid (nt Kostogriz, 2007; Putnam \& Borko, 2000), kes on uurinud praktikakogukonna ja konteksti tähtsust õpetajaks õppimisel, rõhutavad õpetajate õpingute sõltuvust konkreetsetest oludest, st sotsiaalsest tegelikkusest ja sotsiaalsete suhete võrgustikust (sh institutsionaalsetest suhetest). Näiteks, mida toetavamad on kolleegid, seda paremini õpetajad oma professionaalsust enda hinnangul edendavad (Sirk, Ümarik, Loogma, \& Niglas, 2017) ja seda paremini oma ametiga kohanevad (Remmik, Lepp, \& Koni, 2015). Üha uuenevate kutsealaste olude ja sotsiaalsete suhetega toimetulek ei pruugi aga kulgeda ladusalt (Goodson, 2014). Need muutused, millele reageerimiseks pole aega või võimalusi, tekitavad stressi. Seejuures esitab kasvav vajadus tulla toime oma hirmude ja ebakindlusega ilmselt varem või hiljem ka uusi nõudmisi ühiskondlikele institutsioonidele hariduse, teraapia ja poliitika vallas (Beck, 2005). Ebakindlusega toimetulekuks vajalike võimete kujundamisest saab pedagoogiliste institutsioonide, sh ülikoolide üks põhiülesandeid (samas). Seetõttu oleks oluline mõista neoliberaalsete haridusmuutuste osa õpetajate tähenduslikes õpikogemustes.

Siinse uurimuse eesmärk on kirjeldada, kuidas kajastuvad neoliberaalsed haridusmuutused õpetajate õpikogemustes, ja analüüsida, millised õpikogemused on õpetajatele tähenduslikumad. Uurimuses otsitakse vastuseid järgmistele uurimisküsimustele.

1. Kuidas õpetajad tajuvad ühiskonnas toimunud muutusi õpetajatöös?

2. Missuguse tähenduse annavad õpetajad oma õppimisele?

\section{Empiiriline uurimus}

\section{Metoodika ja valim}

Et saada mitmekesist ja rikkalikku uuringumaterjali, järgiti eesmärgistatud valimi moodustamise põhimõtet (vt ka Bogdan \& Biklen, 1998). Sellest seisukohast lähtudes valiti uuringusse õpetajad, kes asusid ametialasele tööle aastatel 1990-1995, mil Eesti ühiskondlikus elus ja haridussüsteemis leidsid aset väga suured muutused: riigikorra vahetus, uue hariduspoliitika väljatöötamine, 
õppekavade arendamine. Intervjueeriti 33 Eesti ópetajat eri kooliastmelt (12 alushariduse, 11 klassi- ja 10 aineõpetajat). Valimisse kuulunud õpetajate keskmine tööstaaž oli 25 aastat: lühim tööstaaž õpetajana 19 aastat ning pikim tööstaaž 27 aastat. Kõik õpetajad olid läbinud kas bakalaureuse- või magistriõppekava. Intervjueeritud õpetajate keskmine vanus oli 47 aastat (noorim vastaja oli 41 aastane ja vanim 53aastane). Kõik uuringus osalejad olid naised. Uuringus osaleti vabatahtlikult, osalejatele selgitati uuringu eesmärki ja anonüümsuspõhimõtet. Õpetajate nimed on artiklis asendatud numbritega (õpetaja 1 - ÕP 1; õpetaja 2 - ÕP 2 jne).

\section{Andmete kogumine}

Uuringus kasutati poolstruktureeritud individuaalseid intervjuusid, mis võimaldavad saada mitmekesist infot intervjueeritavate perspektiivist ning tuua esile nende isiklikud seisukohad, kogemused ja mõtted (Denzin \& Lincoln, 2000; Patton, 2002). Peale suulise intervjuu kasutasime ka kirjalikku, mis võimaldas suurendada valimis osalejate arvu ja koguda ulatuslikum uurimismaterjal. Nii suulise kui ka kirjaliku intervjuu küsimused olid samad.

Uuringu valiidsuse tagamiseks tehti kaks prooviintervjuud, mis kinnitasid meetodi sobivust ja andsid tagasisidet intervjuu küsimuste kohta. Intervjuude küsimusi täpsustati ja tehti muid parandusi (näiteks paluti oppetajatel meelde tuletada mõnda õpikogemust või selgitada põhjalikumalt õppimise tähendust). Uuringu raames tehti 27 suulist intervjuud ja 6 kirjalikku intervjuud, kasutades järgmisi küsimusi (vt Fraenkel \& Wallen, 2003; Patton, 2002):

1) küsimused intervjueeritava tausta kohta (haridus, vanus, töökogemus õpetajana, õpetatavad ained ja õppijate vanus);

2) arvamuse ja väärtushinnangutega seotud küsimused (Kuidas Te mõistate óppimist?, Mida tähendab óppimine Teile kui õpetajale ja óppijale?, Mida soovite veel juurde óppida?, Mis on Teie missioon ópetajana?);

3) kogemuse ja käitumisega seotud küsimused (Missugused muudatused on aastakümnete jooksul ópetamises aset leidnud?, Kuidas on kujunenud Teie kutsealane teekond alates ülikooli lópetamisest?);

4) küsimused teadmiste kohta (Missugustel täiendkoolitustel olete osalenud?, Missuguseid infotehnoloogilisi teadmisi olete omandanud?);

5) tundmustega seotud küsimused (Kuidas Te tundsite ennast ópetajana esimestel tööaastatel?, Milliseid tundeid tekitab Teie töö Teile praegu?).

Iga intervjuu lõpus oli intervjueeritaval võimalus küsimusi omalt poolt täiendada või kommenteerida. Intervjuude kestus oli 45-70 minutit. Suulise intervjuu transkribeeritud teksti oli 157 ja kirjalikku analüüsi 35 lehekülge. 


\section{Andmete analüüs}

Andmete analüüsimiseks kasutati temaatilist analüüsi, mis annab võimaluse esitada uurimistulemusi täpselt ja põhjalikult (Braun \& Clarke, 2006; Vaismoradi, Turunen, \& Bondas, 2013). Kõigepealt transkribeeriti intervjuud sõna-sõnalt ja seejärel loeti materjal korduvalt üle. Intervjuude põhjaliku lugemise tulemusel moodustati koodid ehk tähenduslikud üksused, mis on uurimuse eesmärkidega, sh sotsiaalse õppimisega (Wenger, 1998, 2009) tihedalt seotud. Saadud tulemusi analüüsis kolm autorit eraldi. Uurimuse usaldusväärsuse tagamiseks vahetati omavahel materjali ning diskuteeriti üheskoos tulemuste üle. Sarnased koodid koondati kahte peateemasse (neoliberaalsed haridusmuutused ja õpetaja sotsiaalse õppimise dimensioonid) ja viide alateemasse (õpetaja töö, sotsiaalse keskkonna mõjud, õpetamine kui praktika, õpetamise kogukond, õpetaja identiteet ja õpetamise tähendused). Pea- ja alateemadele anti nimetused ning artikli autorid analüüsisid veel kord saadud tulemuste vastavust töö eesmärkidele ja teoreetilistele seisukohtadele ning tegid täpsustusi, kuni saavutasid konsensuse. Uurimuse usaldusväärsuse tagamiseks saadeti osa analüüsitud materjalist uuringus osalenud õpetajatele tutvumiseks ja täpsustamiseks (vt Flick 2006).

Järgnevalt esitatakse uurimistulemused teemade kaupa, tuues iseloomulikke näiteid intervjuudest. Näidete juurde on märgitud intervjueeritava number.

\section{Tulemused}

\section{Neoliberaalsed haridusmuutused}

\section{Õpetaja töö}

Hariduselu muudatuste algus 1990. aastate algul langes suures osas kokku õpetajate tööle asumise ajaga. Õpetajad kirjeldasid hariduses toimunud muutusi kui vajalikke ja loomulikke, nendega mindi kohe kaasa ja need võimaldasid oma õpetamistegevusi uutmoodi läbi viia. Üks õpetaja selgitas: „Muutused on olnud head, pannud mind kogu aeg õppima" (ÕP 24).

Uuringus osalejad leidsid, et muutused on teinud ópetajad loovamaks, paindlikumaks ja mõistvamaks ning andnud tõuke erialaselt edasi areneda. Kogu haridussüsteemis on intervjueeritavate arvates toimunud suured muutused, eraldi mainiti infotehnoloogia tähtsust ja uute õpetamisvõtete teket. Kui tööd alustades oli õpetajal kasutada paber, tahvel, kriit ja kiled, siis nüüd on olnud võimalik üle minna e-õppele. Digimaailmal ja infotehnoloogial on koolis kindel koht. 
Samas on õpetajad hädas liigse informatsiooniga: olulise teadmise eristamine ebaolulisest ei ole alati kerge. Siin suudavad kogenud õpetajad olla kriitilised, oskavad leida parimaid lahendusi ja teavad, kuidas hoiduda kõige uuega põhjendamatult kaasa minemast. Üks õpetaja kirjeldas olukorda nii.

Meie õppeprogrammid on hästi mahukad, hästi palju on niisugust ebaolulist seal ja tänu taevale, ütleksin, et ei ole enam noor õpetaja, sellepärast et noor õpetaja ei oska terasid sõkaldest eraldada. (ÕP 14)

Kuigi leiti, et toimunud haridusmuutused on vajalikud, peeti oluliseks stabiilsust ja kindlustunnet. Õpetajad ei tea, mis koolis võib hakata toimuma, sest ministrid vahetuvad tihti, rakendatakse uusi ja liiga mahukaid õppekavasid, muutuvad haridusteemade käsitlemise viisid (nt sõnavara õpilaste hindamisel). Kuna sageli on õpetajad kohustatud ümber kirjutama õppekava või seda täiendama ning justkui paremaks tegema, leidis mitu õpetajat, et see on väsitav. Tihti aga ei muuda selline tegevus midagi paremaks ei laste ega nende endi jaoks.

\section{Sotsiaalse keskkonna mõjud}

Suurimate probleemidena tõid õpetajad välja koolivälised asjaolud: muutunud õpilased, väga keerulised perekonnad ja õpetaja töö vähese väärtustamise. Küsimust „Missugust last peab õpetaja muutunud ja muutuvas ühiskonnas kasvatama ja õpetama?" on intervjueeritavad endale korduvalt esitanud. Ühiskond vajab tarka, edukat ja toimetulevat inimest, samas soovib lastelt väga palju muudki. Pingeritta pannakse nii koole kui ka lapsi (juba lasteaiast alates) ja konkurents algab varakult. Lapsi survestatakse ja mõjutatakse saama väga häid hindeid. Õpetajate arvates jääb aga õhku küsimus, mis on tulemus ja tagajärg ning missugust pinget peab noor seejuures taluma.

Õpetajad nõustusid, et tuleviku jaoks peab ette valmistama õnnelikke noori inimesi, kuid küsitav on, kas õppimine peab alati olema lõbus ja huvitav. Leiti, et see peaks olema ka raske, pingutust nõudev ja ajamahukas tegevus ning õppijad ja perekond peaksid mõistma, et kodus on samuti vaja teha tööd ja tundideks tuleb korralikult valmistuda. Niisiis oldi seisukohal, et tähtis on toetada laste huvisid ja vajadusi, kuid sealjuures rõhutati pingutamise ja tööharjumuse kujunemise olulisust.

Õpetajad näevad, et lapsed on kodudes sageli jäetud omapäi ja järelevalveta, neile on pandud suur vastutus, sest vanemad elavad lahus või töötavad välismaal. Üks intervjueeritav väljendas oma muret järgmisel viisil.

Lapsele on pandud täiskasvanu kohustus, see laps peab nüüd olema siis niivõrd tugev isiksus, et ta suudab ennast igal hommikul sundida kooli tulema, sest tal ei ole vanemat, kes seda ütleks. (ÕP 15) 
Samal ajal tõstatasid õpetajad küsimuse, kuidas praegu õpetada klassis, kus on 30 ja rohkem õpilast ning nende seas mitu erivajadusega last, kuid koolis tugisüsteem puudub. Just erivajadustega laste ja parandusõppe teema tulid intervjuudes pidevalt teravalt esile. Seejuures mainisid õpetajad, et selliseid probleeme nende töö algusaastatel ei olnud. Mitu õpetajat oli läbinud vastavad koolitused, et erivajadusega lapsi paremini õpetada.

Intervjueeritavad tõid suure erinevusena esile muutunud koostöö lapsevanematega. Lapsevanemad on teistsugused kui varem, ja kui enne arvestati õpetaja soovitustega, siis nüüd seda enam ei tehta. Leiti, et lapsevanemad on üsna sageli süüdistavad ja nõudlikud, eeldades, et põhilise kasvatustöö teeb ära kool ning vastutus on õpetajatel.

... paar korda olen tundnud end küll nagu klienditeenindaja, kui lapsevanem tuleb siis sellest haridusteenusest räkima, miks ma tema lapsele sellise hinde panin, sest sellise hinde saamine peab ju ikka kellegi muu kui lapse süü olema. (ÕP 27)

Kõik õpetajad olid seda meelt, et ühiskond ei hinda nende tööd väärilise palgaga ega tunnusta piisavalt. Mitu intervjueeritavat selgitas, et kui varem peeti õpetajat ikka maa soolaks ja oma erialal pädevaks inimeseks, siis praegu ümberringi suunatakse ja juhendatakse, kuidas on parim viis lapsi õpetada. Õpetajad on tüdinenud pidevast näpuga näitamisest ja sellest tundest, et neid justkui ei usaldata ning et see haridus, mis on saadud, justkui ei sobivat enam. Kui ei ole pealtnäha pädevust, tekib küsimus, mis sellest tööst siis teha. Arvati ka seda, et kui aastate eest toodi õpetajatele lilli, nende käest küsiti nõu ja nende mõju oli ühiskonnas tunda, siis praeguseks on olukord väga muutunud. Lapsevanemate enesekeskne arusaam õpetajast ja tema tööst kurvastas õpetajaid kõige enam. Õpetajad loodavad, et ehk olukord muutub, sest nüüd toimuvad näiteks aasta õpetajate valimised, samas kõlas ka mõte, et tegelikult on väga häid õpetajaid nii palju, et ühe valimine jätab teised põhjendamatult varju.

Õpetaja töö vähese väärtustamise ja tunnustamisega seoses rääkisid kõik kogenud õpetajad ka sellest, kui oluline on toime tulla pingete ja stressiga ning kuidas ennast tervena hoida. Üks õpetaja põhjendas oma seisukohta järgmiselt.

... selline argielustressoritega toimetuleku oskus on õpetaja töös üüratult oluline. See on hästi oluline, et õpetaja enda tugisüsteem oleks paigas. Et ta tuleks ikkagi väärikalt argipäevas toime ja ei põleks läbi, ei saaks ise haiget. Ja et ei teeks teistele haigelt, sest siin tuleb ka kohe arvestada, et kui õpetaja on katki, siis läheb kõik tema ümber ka katki, kõik tema töö. (ÕP 13)

Intervjuudest selgus, et kogenud õpetajad oskavad ennast rohkem säästa, teavad, kuidas paremini hakkama saada, kuidas end tugevama tunda - on ju 
õpetaja õpilase eeskuju klassiruumis. Samas märkis mitu õpetajat, et nad vajaksid selles valdkonnas eraldi koolitust.

\section{Õpetaja sotsiaalne õppimine}

\section{Õpetamine kui praktika}

Intervjueeritavaid on aastate jooksul kõige enam mõjutanud muutused haridustehnoloogias. Õpetajad on õppinud tundma IKT-vahendeid, otsinud sobivaid digitaalseid õppematerjale ja püüdnud arendada oma haridustehnoloogilist pädevust. Leiti, et nüüd, kui on e-kool ja e-lasteaed, siis on olemas ka väga head võimalused tehnoloogia kasutamiseks ja seetõttu on töö muutunud palju mitmekesisemaks. Üks õpetaja võrdles praegust tööd algusaastate omaga.

Kui ma oma tööd alustasin, siis see tehnika pool ja arvutikursused olid nii keerulised. Nüüd teen ma ise nii keerulisi asju, et see vahe tundub nii meeletu, tehniline areng on aidanud õpetaja tööd kergemaks teha. (ÕP 5)

Kui õpetaja kasutab huvitavaid e-õppe meetodeid, siis tekib ka õpilastes huvi ja tahe materjali omandada ning õpitavast ainest rohkem teada saada. Õpetajad rääkisid, et lapsi paelub mitte lihtsalt rääkimine, vaid piltide kasutamine, samuti ise läbitegemine, sest nii sünnib soov edasi uurida ja proovida. Selline laste huvi ja õhin omakorda motiveerivad õpetajat otsima uusi ja mitmekesiseid õpetamisvõimalusi. Koolitustel on tutvutud erinevate digitaalsete õppematerjalide koostamise võimalustega (nt veebipõhised töölehed, esitlused, testid), mis kõik on pakkunud õpetajatele väga palju uusi ideid oma töö rikastamiseks. Samas julgevad õpetajad tunnistada õpilastele, kui midagi IKT-valdkonnas ei osata.

Ma olen raudselt rumalam kui lapsed tehnika alal ja ma ei häbene neile seda öelda. Nad tulevad hea meelega ja aitavad ja saavad olla õpetajast targemad ja minul ei ole see häbiasi, et nad minust targemad on selles osas. Nad on targemad, sest nad on nende asjadega üles kasvanud. Nemad ei karda! Täiskasvanuna kardad sa midagi ära rikkuda, aga nemad ei karda (ÕP 14).

Infotehnoloogia kasutamisest rääkides tõid õpetajad välja mitmed õpilastega seotud ohud alates sellest, et nüüdne laste maailm on liiga pildiline ja lapsed on harjunud, et õpetus peab olema väga visualiseeritud. Sageli ei oska algklassiõpilased enam paberil kirjutada ega joonistada, paberraamatuid loetakse vähe. Õpetajad näevad, et kui ollakse liiga palju arvutis, siis väheneb laste suhtlusoskus ning laste kõne ja sõnavara kannatavad. 
Uuringus osalejad leidsid, et lastega suhtlemine koolis on muutunud ja valdavaks on saanud lapse-/õppijakeskne õpetus - õpetajate töö aluseks on laps. Aastate jooksul on õpitud märkama laste eripärasid ning püütud nende individuaalsust ja vajadusi üha rohkem oma töös arvestada. Õpetajad selgitasid, et lapsed on teistsugused kui varem ja neile tuleb enam tähelepanu pöörata, neid tuleb rahulikult kuulata ja kõige tähtsam on nendega rääkida, suhelda inimlikul tasandil. Lastel on väga palju probleeme ja küsimusi elu kohta, nad elavad palju virtuaalses maailmas ja tegelik elu võib neile jääda üsna võõraks. Lapsevanematel ei ole aega oma lastega vestelda, tulemuseks on segaduses ja selgusetuses lapsed, kes ei tea, kuidas ümbritsevat mõista või kuidas käituda. Üks klassiõpetaja täpsustas olukorda järgmisel viisil.

Ma kuulan lapsi. Me arutame väga paljusid teemasid. Ma suudan luua seoseid igapäevaeluga, tuua hästi palju näiteid, läbi arutada, miks mingid asjad on vajalikud. (ÕP 3 )

Laste õpikeskkond ja õppimine on muutunud, lastel on palju võimalusi infot kätte saada. Sageli on laste ümber liigset infomüra. See on toonud kaasa olukorra, kus lapsed on muutunud tuimaks ja uute stiimulite suhtes immuunseks. Nad ei oska eristada olulist ebaolulisest, ja siin vajavad õppijad täiskasvanu toetust. Intervjueeritavad rääkisid, et sageli arutavad nad tundides laste jaoks olulisi teemasid, jättes seejuures õpitava teema tagaplaanile. Tähtis on lastes eelkõige üldinimlikke väärtusi kujundada, mitte niivõrd teadmisi edastada. Tulemuseks on laste ja õpetaja vahelised head suhted ning üksteisemõistmine.

Õpetajad tajuvad, et nad on lastega võrdväärsed koostööpartnerid ja et õppijatega suheldes tuleb olla kannatlik ning säilitada rahulik meel. Arusaamatuste korral tuleb pakkuda lahendusi, kuulata ära lapse lahendused ja siis üheskoos midagi ette võtta. Kõige raskem, nagu tunnistasid õpetajad, on andestada lapsele ja mitte pidada tema vastu viha, vaid unustada sündmus. Kui vaja, siis tuleb paluda lapselt vabandust ja rääkida asjad selgeks.

\section{Õpetamise kogukond}

Kogukonna tähtsust ja mõju õpetaja töös rõhutasid kõik intervjueeritavad. Läbisaamine kolleegidega on tähtis, kuna ühine eesmärk ja üksteisemõistmine rikastavad õpetajat. Head suhted kolleegidega on aidanud püsida pikka aega tööl. Räägiti, et kolleegid olid olulised juba tööle asumise algusaastatel, kui puututi kokku esimeste raskustega. Mitu õpetajat tunnistas, et ülikooliõpingud olid nende jaoks liiga teoreetilised või isegi sisult aegunud, seepärast olid esimesed kohtumised töömaailmaga üsna keerulised. Õpetajale olid siis suureks toeks vanemad kolleegid, kes aitasid kohaneda kooliga ning leida õigeid ja 
vajalikke õppematerjale ja -meetodeid. Kui koolikeskkond ei sobinud, oli liiga vanameelne või jäik, siis õpetajad otsisid teisi koole, et jätkata oma tööd eelmisest erinevas keskkonnas.

Nüüd, kogenud õpetajana, tõdesid intervjueeritavad, et praktikandid või noored õpetajad on samuti kooli teretulnud ja nad on suureks väärtuseks koolielus, tuues kaasa uusi lähenemisviise ja värskeid ideid.

Ma väga toetan noori õpetajaid. Praegu on mul noor õpetaja paariliseks. Ja noor õpetaja toob alati uusi tuuli tööellu, kaasaegseid mõtteid ja tegevusi, mis loovad vaheldust. Aga noor inimene on selline, et alati ei tule küsima, siis on niimoodi, et taktitundeliselt vaatan, kas vajab abi või ei vaja abi, ja huumor aitab ka. (ÕP 11)

Intervjuudest ilmnes, et praegu kohtutakse kolleegidega pidevalt, vesteldakse ja arutatakse, kuidas üksteist toetada. Lisaks leiti, et ühistes kokkusaamistes analüüsitakse koolitustel omandatud uusi teadmisi, jagatakse omavahel materjale ja diskuteeritakse selle üle, kuidas neid kasutada igapäevatöös.

Kui osaletakse erinevatel koolitustel, siis näiteks kolleegidele tehakse hiljem ülevaade ning esitatakse kokkuvõtteid. On loodud ka klubid, kus vahetatakse mõtteid, diskuteeritakse ja jagatakse õpetajalt õpetajale kogemusi. (ÕP 3)

Täiendusõppe suhtes olid õpetajad üsna kriitilised, selgitades, et tihti ei arvesta koolitajad nende pikaajaliste töökogemustega. Loengud on kõigile koolitustest osavõtjatele ühesugused, kas liiga lihtsakoelised või liiga teoreetilised ja elukauged. Õpetajad vajaksid koolitusi, kus antakse tõeliselt uusi teadmisi ja jagatakse tänapäevaseid seisukohti. Kõige tähtsam on aga see, et saadud teadmisi saaks kohe oma klassis rakendada. Lisaks tõdeti, et täienduskoolitusel on liiga palju paaris- või rühmatöid ja sel viisil õppimine ei õigusta ennast, sest koolitajalt oodatakse eelkõige uut teavet. Õpetajad rääkisid, et naaberkooli õpetajatega kohtutakse niikuinii ning eraldi koolitusel nendega lobisemine ja kohvi joomine on vaid aja raiskamine.

Intervjueeritavad tõdesid, et õpetajate kogukond on muutumas järjest olulisemaks. Hinnatakse seda, et koolis on hästi toimiv meeskond, kus toetatakse ja aidatakse üksteist, aga ei kiideta niisama, vaid vajaduse korral ka kritiseeritakse ja tuuakse välja kolleegi nõrgad kohad. Tähtis on käia üksteise tundides ja analüüsida neid hiljem, et õppida niiviisi tundma kolleegide tööd. Tajutakse, et tehakse ühist tööd ja ka eesmärgid on kõigil samad, seepärast on suudetud nii kaua samas koolis töötada. Kolleegide ja juhtkonna tunnustus on ka märk sellest, et töö sobib. 


\section{Õpetaja identiteet ja õpetamise tähendused}

Rääkides identiteedist, arutlesid intervjueeritavad, et õpetaja roll on vastuolus ühiskonna ja kooli kontekstiga. Haridus ja koolitus on ühiskonnas tähtsal kohal ning hea haridus on edukuse näitaja. Samas pannakse õpetajale väga suur koormus ja vastutus, aga tema tööd ei nähta ega tunnustata. Õpetaja positsioon ei ole ühiskonnas stabiilne, sageli on see päevakajalistest sündmustest liialt mõjutatud. Ometi leidsid uuringus osalenud õpetajad, et neil on täita vastutusrikas roll ja nad soovivad anda endast parima. Esimestel aastatel ei tajutud vastutust, mis kaasnes selle ametiga, tööd võeti kergemalt. Mida aasta edasi, seda rohkem mõistetakse, et kui teadmiste ja oskuste vundament jääb nõrgaks, siis on lapsel raskusi edasi arenemise ja õppimisega.

Vastutuse ja oma rolli tunnetamine ning avatus uutele ideedele on võimaldanud õpetajatel pikka aega oma tööd teha ning sellest rõõmu tunda. Kogenud eesti keele õpetaja selgitas oma rolli nii.

[...] sellepärast, et mulle on öeldud ka seda, et kuidas sa ära ei tüdine, et mõtle, kui palju sa oled juba õpetaja olnud ja igal aastal räägid sedasama ühte luuletajat ja ühte ja sama kirjanikku. [...] Aga iga klass on omamoodi ja ühes klassis sa saad rääkida palju rohkem ja palju sügavamalt ja teine klass [...] noh, ta ei võta seda vastu nii hästi. (ÕP 14)

Muutused ühiskonnas mõjutavad õpetaja identiteeti ja ootused õpetaja rolli suhtes on väga suured. Intervjueeritavad rääkisid, et sageli nad ei ole ainult õpetajad, vaid ka sotsiaalpedagoogid või sotsiaaltöötajad, sest lastega seotud probleemid on sotsiaalse iseloomuga. Vanemad on tööl või välismaal, aega laste jaoks ei ole ning tihti kulgeb suhtlus kooli ja kodu vahel vaid mobiiltelefonidearvutite abil. Ühiskond oma tugisüsteemidega toetab selles lapsi vähe ja õpetajad peavad võtma laste toetamise vastutuse enda kanda.

Intervjuude analüüsist ilmnes, et õpetajad väärtustavad kõrgelt oma töökogemusi ja õpetaja tööd. Tõdeti, et praktika on muutnud nad avatumaks ja paindlikumaks, suhtumine lastesse, lapsevanematesse ja kolleegidesse on sallivam. On märgata, et õpetajad on õppinud uskuma inimeste arenemisvõimesse ja reguleerivad oma käitumist selle järgi. Samuti mõistsid intervjueeritavad, et pikaajalised õpetamiskogemused on laiendanud silmaringi, andnud erinevaid praktilisi oskusi ja pakkunud võimalusi läheneda erinevalt mitmesugustele küsimustele. Õpetaja rolli tajutakse enesearengut mõjutavana ja seejuures ollakse avatud erinevatele kogemustele, mida elu ja õppekeskkond oma mitmekesisuses pakuvad. Niisiis tajutakse õpetamist õppimisena. 
Kindlasti on kõik see [õpetamine] mind inimesena mõjutanud. Ma arvan, et see on lihtsalt nii pikk aeg, et inimene kasvabki inimesena selle aja jooksul. (ÕP 1)

Olen õppinud õppima elust enesest. (ÕP 15)

Märgiti, et palju õpitakse teisi õpetades: õpitakse oma õpilastelt, eduelamus saadakse laste kaudu. Samuti ópitakse teiste koolide kolleegidelt, maailmas ringi käies ning ennast pidevalt täiendades ja tagasisidet saades. Laste silmade sära, siirus ja vahetu suhtlemine on see, mis on pannud õpetajaid õppima, lisaks teadmine enda vajalikkusest ja võimekusest õpilastele midagi anda.

Ma tunnen väljastpoolt, et ma olen õiges kohas, see väline hinnang mõjutab ka minu enesehinnangut, et ma saan tööd jätkata; tagasiside ja kindlustunne, et ma teen õiget asja, laste, vanemate, kolleegide poolt; teadmine, et mind on ikka vaja. (ÕP 6)

Pidev õppimine on olnud õpetajate jaoks lisaväärtus, mis võimaldab teha oma tööd edukamalt ja professionaalsemalt.

\section{Arutelu ja kokkuvõte}

Meie eesmärk oli kirjeldada, kuidas kajastuvad haridusmuutused õpetajate õpikogemustes, ning analüüsida, millised õpikogemused on õpetajatele tähenduslikumad. Selgus, et õpetajad tajuvad oma õppimist kirjeldades haridusmuutusi nii enda tegevustes ja kogemustes, end ümbritsevas kogukonnas kui ka oma professionaalses identiteedis. Nii nagu teistes riikides (vrd Borko et al., 2010), on ka Eestis õpetaja õppimine tugevalt seotud sotsiaalse kontekstiga.

Muutuste kirjeldamisel toovad õpetajad positiivsena esile majanduslike olude paranemisega seotud asjaolud: haridustehnoloogiliste vahendite kasutamise vajaduse ja võimaluse ning õppematerjalide paljususe ja kättesaadavuse. Tehnoloogiliste muutustega lähevad õpetajad suure rõõmuga kaasa. Paraku kerkib õpetajate õppimise kirjeldustes pidevalt esile vastuolu liberaalsete väärtuste (nagu õppija individuaalsuse väärtustamine ja humaansus) ning haridustulemuslikkusele ja -mõõdetavusele orienteerituse vahel. Sama vastuolu võib märgata paljudes demokraatlikes riikides (Apple, 2006; McGregor, 2009; Olssen, 2004). Ka perede sotsiaal-majanduslikud probleemid, mis peegelduvad laste ja noorte elus, jõuavad õpetajateni ning mõjutavad õppeprotsessi ja koostööd lapsevanematega. Niisiis peavad õpetajad leidma tasakaalu õppija vajaduste ning võimaluste arvestamise ja akadeemilise edu tagamise vahel. Õpetajad tajuvad, et kõige tähtsam on pakkuda õppijatele keerukas ja vastuolulises 
neoliberaalses olukorras tuge. Seda tuge püütakse anda oma tegevust tänapäeva oludele kohandades ning õppijate vajadustele keskendudes, seejuures mõistetakse muutuste paratamatust ja vajadust ise pidevalt muutuda (vrd Britzman, 2007).

Eelkirjeldatud olukord toob õpetajates esile mitmed pinged, millest kõige tugevamat põhjustab õpetamisalaste tavaarusaamade ülevõimendamine. Õpetajad näevad end püsiva välise surve all, sest nende hinnangul ei mõista lapsevanemad ja laiem avalikkus nende tegevuse sügavat sisu ja eripära, st õpetamist ei käsitleta tipp-professionaali tegevusena - kõiki avalikkuses levivaid arvamusi õpetamisest esitletakse ja käsitletakse võrdväärsena. Samal ajal esitatakse õpetajatele kutsestandardiga väga rangeid nõudeid (Kutsestandard ..., 2005, 2013). Lisaks on liberaalses ühiskonnas haridustegelikkus väga variatiivne, mistõttu eeldatakse, et õpetaja suudab kõigele reageerida ja erinevate muutustega kohaneda. Need nõuded kujundavad ka õpetaja minapilti (Goodson, 2014) - õpetajad mõistavad hästi, mis valdkonnas vajaksid nad täiendõpet. Nii rangete nõudmiste taustal nõuavad õpetajad palju ka täiendõppelt, mis sageli ei vasta ootustele, tekitades pettumust.

Kuigi õpetajad mõistavad kutsealase arengu ja õppimise olulisust, ei saa nad sageli selleks oma vajadustele vastavat professionaalset tuge. Kolleegide tugi, enese töö sisu pidev (ümber)mõtestamine ja õpetamistegevuste täiendamine ning õppijatelt saadav positiivne tagasiside aitavad õpetajatel pettumust ja pingeid ületada. Samas ei tohiks pingetega toimetulek olla ainult õpetajate endi ja nende lähemate kolleegide kanda. Õpetajad vajaksid ilmselt enam asjakohast täiendõpet ja nõustamist, mille eest peaksid hea seisma haridusasutused ja õpetajaid ettevalmistavad ülikoolid (vrd Beck, 2005). Seda peamiselt seepärast, et suur osa õpetaja töös valitsevatest pingetest pole otseselt põhjustatud õpetaja enda tegevusest või tegevusetusest, vaid peegeldavad ühiskonna seisundit ja arengut.

Niisiis toetavad ka siinse uurimuse tulemused varasemaid andmeid, mis kajastavad õpetajate rahulolematust oma tööle antavate hinnangute ja kutse staatusega (OECD, 2008, 2013). Samas on õpetajad oma töö põhisisuga õpetamisega - rahul (samas). Lisaks selgub, et ilmselt vajavad õpetajad sotsiaalsete muutuste mõistmiseks ja mõtestamiseks enam tuge. Pingeid aitaks vähendada senisest parem tugisüsteem, mis seab peale õppijate selgesse fookusesse ka õpetaja, seejuures tuleks tunnistada, et õpetajad töötavad paratamatult muutuvates oludes ja erinevate õppijatega ning muutuste ja erinevustega toimetulekuks tipp-professionaali tasemel vajavad nad pidevat süsteemset ning asjatundlikku abi. Samas tuleks professionaalse õpetaja tegevust ja õpetamisalaseid otsuseid usaldada, eeldades, et ta näeb õppimise tervikkonteksti ning toimib oludele vastavalt parimal moel. 
Praeguse uurimuse tulemusi analüüsides selgus muu hulgas, et õpetajate sotsiaalseid muutusi kajastavad óppimiskogemused ei erine ainevaldkonniti ega õppijate vanuse järgi oluliselt. Niisiis võib eelkirjeldatud tulemusi pidada Eesti õpetajaskonnale üldiselt iseloomulikuks. Samas takistavad sellise üldistuse tegemist mitmed asjaolud. Esiteks, uuringus kasutati intervjuud, mis võimaldab uuritavatel selgitada põhjalikult oma mõtteid, arusaamu ja kogemusi. Põhiline info koguti suulise intervjuu abil, kuid kasutati ka kirjalikku intervjuud, sest eesmärk oli suurendada uuringus osalejate arvu ja koguda mitmekesist lisainfot. Selle tõttu vähenes aga andmete võrreldavus. Teiseks võib piiranguks pidada, et valimisse ei kuulunud vene õppekeelega õpetajad. Kolmandaks kasutati uurimismetoodikat, mis ei näita selgeid statistilisi seoseid, vaid võimaldab kirjeldada õpetajate tegevusi ja nende tähendusi õpetajate endi perspektiivist. Nii õpetajate esmaõppe, täiendõppe kui ka tugisüsteemide kavandamisel võiks õpetajate enda vajadusi kutsealase arengu toetamise ja pingete ületamise vaatenurgast edaspidi veelgi põhjalikult uurida.

\section{Tänusõnad}

Uurimus on valminud grandi nr IUT18-2 „Õpetajate professionaalsuse ja professionalismi muutuv kontekst“ toel. Täname uuringus osalenud õpetajaid.

\section{Kasutatud kirjandus}

Apple, M. W. (2006). Producing inequalities: Neo-liberalism, neo-conservatism, and the politics of educational reform. In H. Lauder, P. Brown, J.-A. Dillabough, \& A. H. Halsey (Eds.), Education, globalization \& social change (pp. 468-489). Oxford: Oxford University Press.

Autio, T., Kuurme, T., \& Mikser, R. (2013). Haridus. R. Mikser (toim.), Haridusleksikon (lk 69-77). Tallinn: Eesti Keele Sihtasutus.

Bates, R., \& Townsend, T. (2007). The future of teacher education: Challenges and opportunities. In T. Townsend \& R. Bates (Eds.), Handbook of teacher education: Globalization, standards and professionalism in times of change (pp. 727-734). Dordrecht: Springer.

Beck, U. (2005). Riskiühiskond. Teel uue modernsuse poole. Tartu: Tartu Ülikooli Kirjastus.

Bogdan, R. C., \& Biklen, S. K. (1998). Qualitative research for education: An introduction to theory and methods (3rd ed.). Boston: Allyn and Bacon.

Borko, H., Jacobs, J. K., \& Koellner, K. (2010). Contemporary approaches to teacher professional development. In P. Peterson, E. Baker, \& B. McGaw (Eds.), International encyclopedia of education (3rd ed., pp. 548-556). Amsterdam: Elsevier. https://doi.org/10.1016/B978-0-08-044894-7.00654-0 
Braun, V., \& Clarke, V. (2006). Using thematic analysis in psychology. Qualitative Research in Psychology, 3(2), 77-101. https://doi.org/10.1191/1478088706qp063oa

Britzman, D. P. (2007). Teacher education as uneven development: Toward a psychology of uncertainty. International Journal of Leadership in Education, 10(1), 1-12. https://doi.org/10.1080/13603120600934079

Bullough, R. V., \& Gitlin, A. D. (2001). Becoming a student of teaching: Linking knowledge production and practice of teaching (2nd ed.). New York: Routledge Falmer.

Cochran-Smith, M. (2006). Policy, practice and politics in teacher education. California: Corwin Press.

Coldron, J., \& Smith, R. (1999). Active location in teachers' construction of their professional identities. Journal of Curriculum Studies, 31(6), 711-726. https://doi.org/10.1080/002202799182954

Darling-Hammond, L. (1990). Teachers and teaching: Signs of a changing profession. In W. R. Houston (Ed.), Handbook of research on teacher education: A project of the Association of Teacher Educators (pp. 267-290). New York: Macmillan Publishing Company.

Day, C. (2004). School reform and transitions in teacher professionalism and identity. International Journal of Educational Research, 37(8), 677-692. https://doi.org/10.1016/S0883-0355(03)00065-X

Day, C. (2005). The challenge to be the best: Research and the teacher. In P. M. Denicolo \& M. Kompf (Eds.), Connecting policy and practice: Challenges for teaching and learning in schools and universities (pp. 158-176). London: Routledge.

Day, C., Elliot, B., \& Kington, A. (2005). Reform, standards and teacher identity: Challenges of sustaining commitment. Teaching and Teacher Education, 21(5), 563-577. https://doi.org/10.1016/j.tate.2005.03.001

Denzin, N. K., \& Lincoln, Y. S. (Eds.) (2000). Handbook of qualitative research. (2nd ed.). Thousand Oaks: SAGE Publications.

Eesti elukestva óppe strateegia 2020 (2014). Tallinn: Haridus- ja Teadusministeerium. Külastatud aadressil https://www.hm.ee/sites/default/files/strateegia2020.pdf.

Flick, U. (2006). An introduction to qualitative research (3rd ed.). London, Thousand Oaks: SAGE Publications.

Flores, M. A., \& Day, C. (2006). Contexts which shape and reshape new teachers' identities: A multi-perspective study. Teaching and Teacher Education, 22(2), 219232. https://doi.org/10.1016/j.tate.2005.09.002

Fraenkel, J. R., \& Wallen, N. F. (2003). How do design and evaluation in education (4th ed.). New York: McGraw-Hill Companies.

Furlong, J., Barton, L., Miles, S., Whiting, C., \& Whitty, G. (2000). Teacher education in transition: Re-forming professionalism? Buckingham: Open University Press.

Goodson, I. F. (2014). Investigating the life and work of teachers. Eesti Haridusteaduste Ajakiri, 2(2), 28-47. https://doi.org/10.12697/eha.2014.2.2.02b

Green, A. (1997). Education, globalization and the nation state. London: Palgrave Macmillan.

Grubb, W. N., \& Lazerson, M. (2006). The globalization of rhetoric and practice: The education gospel and vocationalism. In H. Lauder, P. Brown, J.-A. Dillabough, \& A. H. Halsey (Eds.), Education, globalization \& social change (pp. 295-307). Oxford: Oxford University Press. 
Hargreaves, A. (2006). Four ages of professionalism and professional learning. In H. Lauder, P. Brown, J.-A. Dillabough, \& A. H. Halsey (Eds.), Education, globalization \& social change (pp. 673-691). Oxford: Oxford University Press.

Imants, J. (2003). Two basic mechanisms for organisational learning in schools. European Journal of Teacher Education, 26(3), 293-311. https://doi.org/10.1080/0261976032000128157A

Kitsing, M., Boyle, A., Kukemelk, H., \& Mikk, J. (2016). The impact of professional capital on educational excellence and equality in Estonia. Journal of Professional Capital and Community, 1(3), 237-252. https://doi.org/10.1108/JPCC-03-2016-0003

Kostogriz, A. (2007). Spaces of professional learning: Remapping teacher professionalism. In A. Berry, A. Celmans, \& A. Kostogriz (Eds.), Dimensions of professional learning: Professionalism, practice and identity (pp. 23-36). Rotterdam: Sense Publishers.

Kutsestandard. Õpetaja V (2005). Hariduse kutsenõukogu. Külastatud aadressil http://www.kutsekoda.ee/et/kutseregister/kutsestandardid/10086813/lae.

Kutsestandard. Õpetaja, tase 7 (2013). Hariduse kutsenõukogu. Külastatud aadressil http://www.kutsekoda.ee/et/kutseregister/kutsestandardid/10086813/lae.

Lauriala, A. (1997). Development and change of professional cognitions and action orientations of Finnish teachers (Doctoral dissertation). Oulu: Oulun Yliopisto.

Lepik, M., Loogma, K., \& Talts, L. (2013). Õpetajakutse transformatsioon ühiskonnas: toimetulekustrateegiad, pedagoogilised uskumused ning tööidentiteet. E. Krull et al. (toim.), Õpetajate professionaalne areng ja selle toetamine (lk 227-234). Tartu: Eesti Ülikoolide Kirjastus.

Loughran, J. (2002). Effective reflective practice: In search of meaning in learning about teaching. Journal of Teacher Education, 53(1), 33-43. https://doi.org/10.1177/0022487102053001004

Luukkainen, O. (2000). Opettaja vuonna 2010. Opettajien perus- ja täydennyskoulutuksen ennakointihankkeen (OPEPRO) selvitys 15. Loppuraportti. Helsinki: Opetushallitus.

McGregor, G. (2009). Educating for (whose) success? Schooling in an age of neoliberalism. British Journal of Sociology of Education, 30(3), 345-358. https://doi.org/10.1080/01425690902812620

Mikser, R., \& Heidmets, M. (2013). Hariduspoliitika. R. Mikser (toim.), Haridusleksikon (lk 89-94). Tallinn: Eesti Keele Sihtasutus.

Männiste, T. (2014). Nõukogudeaegse kõrgharidusega keskealised siirdeaja elukestva õppe keskkonnas. Eesti Haridusteaduste Ajakiri, 2(2), 48-78. https://doi.org/10.12697/eha.2014.2.2.03

Newman, F. M., Marks, H. M., \& Gamoran, A. (1996). Authentic pedagogy and student performance. American Journal of Education, 104(4), 180-312. https://doi.org/10.1086/444136

Olssen, M. (2004). Neoliberalism, globalisation, democracy: Challenges for education. Globalisation, Societies and Education, 2(2), 231-275. https://doi.org/10.1080/14767720410001733665

OECD (2008). TALIS 2008. Technical report. Paris: OECD. Retrieved from https://www.oecd.org/edu/school/44978960.pdf. 
OECD (2013). TALIS 2013. Technical report. Paris: OECD. Retrieved from http://www.oecd.org/education/school/TALIS-technical-report-2013.pdf.

OECD (2016). PISA 2015 results. Retrieved from http://www.oecd.org/pisa/.

Patton, M. Q. (2002). Qualitative research and evaluation methods (3rd ed.). Thousand Oaks: SAGE Publications.

Putnam, R. T., \& Borko, H. (2000). What do new views of knowledge and thinking have to say about research on teacher learning? Educational Researcher, 29(1), 4-15. https://doi.org/10.3102/0013189X029001004

Põhikooli ja gümnaasiumi riiklik õppekava (2007). Riigi Teataja I, 2007, 40, 294. Külastatud aadressil https://www.riigiteataja.ee/akt/12841613.

Remmik, M., Lepp, L., \& Koni, I. (2015). Algajad õpetajad koolijuhi ja kolleegide toetusest esimestel tööaastatel. Eesti Haridusteaduste Ajakiri, 3(1), 173-201. https://doi.org/10.12697/eha.2015.3.1.08

Rizvi, F. A., \& Lingard, B. (2006). Globalization and the changing nature of the OECD's educational work. In H. Lauder, P. Brown, J.-A. Dillabough, \& A. H. Halsey (Eds.), Education, globalization \& social change (pp. 247-260). Oxford: Oxford University Press.

Robson, J. (2006). Teacher professionalism in further and higher education: Challenges to culture and practice. Abingdon: Routledge.

Ruus, V-R. (2006). Õpetaja professionaalsuse ning õpetajahariduse kaasaegsed arengusuundumused. Tallinn: Tallinna Ülikool.

Ruus, V-R. (2010). Õpetajakutse mitmetasandiline ja -dimensiooniline mudel ning strateegilised sõlmpunktid. V. Ruus \& E-S. Sarv (koost.), Oppetaja esmaharidus. Olukord ja probleemid 21. sajandi algul (lk 7-35). Tallinn: Tallinna Ülikool.

Ruus, V-R., \& Timoštšuk, I. (2014). Searching for constant innovation in teacher education curricula: The case of Estonia. Problems of education in the 21st century (Vol. 62, pp. 97-108). Šiauliai: Scientific Methodical Center „Scientia Educologica“.

Sarv, E.-S. (1999). Political and social transformations: Analysis in the Estonian context. In H. Niemi (Ed.), Moving horizons in education: International transformations and challenges of democracy (pp. 39-67). Helsinki: University of Helsinki.

Sirk, M., Ümarik, M., Loogma, K., \& Niglas, K. (2017). Koostöö kutseõpetaja professionaalsust määrava tegurina. Eesti Haridusteaduste Ajakiri, 5(2), 80-105. https://doi.org/10.12697/eha.2017.5.2.04

Stokking, K., Leenders, F., De Jong, J., \& Van Tartwijk, J. (2003). From student to teacher: Reducing practice shock and early dropout in the teaching profession. European Journal of Teacher Education, 26(3), 329-350. https://doi.org/10.1080/0261976032000128175

Timoštšuk, I. (2011). Õpetajaks õppivate üliõpilaste kutseidentiteet (doktoritöö). Tallinn: Tallinna Ülikool. Külastatud aadressil http://www.etera.ee/zoom/2203/view?page $=3 \& \mathrm{p}=$ separate\&view $=0,0,2067,2834$

Timoštšuk, I., \& Ugaste, A. (2010). Student teachers' professional identity. Teaching and Teacher Education, 26(8), 1563-1570. https://doi.org/10.1016/j.tate.2010.06.008

Trent, J. (2010). Teacher education as identity construction: Insights from action research. Journal of Education for Teaching, 36(2), 153-168.

https://doi.org/10.1080/02607471003651672 
Vaismoradi, M., Turunen, H., \& Bondas, T. (2013). Content analysis and thematic analysis: Implications for conducting a qualitative descriptive study. Nursing \& Health Sciences, 15(3), 398-405. https://doi.org/10.1111/nhs.12048

Wenger, E. (1998). Communities of practice: Learning, meaning, and identity. Cambridge: Cambridge University Press.

Wenger, E. (2009). A social theory of learning. In K. Illeris (Ed.), Contemporary theories of learning (pp. 209-218). London: Routledge.

Wringe, C. A. (2010). Autonomy. In P. Peterson, E. Baker, \& B. McGaw (Eds.), International encyclopedia of education (pp. 121-126). Amsterdam: Elsevier.

https://doi.org/10.1016/B978-0-08-044894-7.00575-3 


\title{
Teachers' learning experiences in the context of neoliberal educational change
}

\author{
Inge Timoštšuk ${ }^{\text {al }}$, Aino Ugaste ${ }^{\mathrm{a}}$, Kristi Mets-Alunurma ${ }^{\mathrm{a}}$ \\ ${ }^{a}$ Institute of Educational Sciences, Tallinn University
}

\begin{abstract}
Summary
Our aim is to describe how neoliberal changes in society are reflected in the teacher's learning experiences and to analyse which learning experiences are more meaningful to teachers. The curriculum is changing constantly, and coping with this change requires learning, however, it creates certain tensions (frustration and stress) among teachers.

According to Britzman (2007) the problem is inevitable, and she calls it uncertainty of teaching, which is driven by both the variability of situations and educational policy changes. An outstanding example of such changes is the democratic social order achieved by Estonia's regaining of independence in 1991 (cf. e.g., Kitsing et al., 2016).

Education was influenced by market economy principles and the liberal worldview. Similar changes in education continue, but are no longer so revolutionary and take place on a step-by-step basis as Estonia follows the global trend over the last decade (Ruus \& Timoštšuk, 2014).

The effect of such ideological and economic trends appears throughout the desire for comparability of educational outcomes (Olssen, 2004). It is expected that teachers will be able to bring pupils to better educational outcomes. Estonian teachers have achieved very remarkable results, and have improved over the years (OECD, 2016). Meanwhile, market economies societies appear to be cutting costs in education (Bates \& Townsend, 2007; Cochran-Smith, 2006; Kostogriz, 2007).

In Estonia, it is more about cost efficiency - money is not significantly reduced, but it is redistributed. For example, the teacher's workload is being redesigned and the school network reorganized. At the same time, it is known that the desire to achieve better results with fewer resources makes teachers resentful, and conflicts between external expectations and self-perceptions create tensions (Bullough \& Gitlin, 2001; Hargreaves, 2006).
\end{abstract}

Institute of Educational Sciences, Tallinn University, Narva Road 25, 10120 Tallinn, Estonia; inge.timostsuk@tlu.ee 
The dissatisfaction of Estonian teachers in their daily work is heavily related to out-of-school conditions less dependent on themselves and colleagues, such as low salaries and low public recognition of teachers in society and the media (OECD, 2013). Only 13.7\% of teachers perceive that society values their work (ibid.). According to the same results, the prevalent majority (90\%) of teachers is satisfied with their work - this is a significant contradiction. Unfortunately, if the teacher's work-related tensions increase and cannot be overcome, this will result in opting out of the teaching profession or having a very short career in education (Day, 2004; Day et al., 2005; Flores \& Day, 2006; Stokking et al., 2003). This possibility should be avoided in the light of ageing teachers (OECD, 2008, 2013).

In order to obtain a diverse and rich research material concerning teachers' learning experiences, 33 Estonian teachers were interviewed. The study used the principle of targeted sampling (see Bogdan \& Biklen, 1998). All teachers started work between 1990 and 1995, when big changes in Estonia's social life and in the education system took place: changes in the state system, the development of a new educational policy, the development of curricula.

Interviewees were asked to talk about the changes that have taken place in Estonia during the following decades and how these changes have influenced them as learners and teachers. They were asked to explain how they understood learning. The interviewees discussed their mission and role and explained with whom they learn. Finally, we wanted to find out how the teacher evaluated and appreciated his/her long-term work and what he/she would still like to learn.

The data analysis is based on thematic analysis, which provides an opportunity to present the research results accurately, precisely and abundantly (Braun \& Clarke, 2006). The interviews were initially transcribed literally, and then the material was repeatedly read. As a result of in-depth reading of the interviews, codes were created, for example, the meaningful units closely related to the goals of the study, including dimensions of social learning (Wenger, 1998, 2009).

Describing the changes, teachers pointed out the positive aspects of improving their economic situation: the need and opportunity for the use of educational technology and the plurality and availability of educational materials. Teachers will gladly accept such changes. At the same time, in the descriptions of teachers' learning, the contradiction between liberal values (such as appreciation of the learner's individuality and humanity) and the orientation of educational performance and measurement are constantly highlighted. The same contradiction is felt in many democratic countries (McGregor, 2009; Olssen, 2004). The socio-economic problems of families, which are reflected in the lives of children and young people, influence the learning process and cooperation 
with parents. Therefore, teachers need to find a balance between being aware of the needs and opportunities of the learners and ensuring academic success. Teachers explain this as very important since they must support students first and foremost in a complex and controversial neoliberal situation. This support is attempted by adapting teaching methods to the contemporary situation and greater awareness of the needs of learners, while recognizing the inevitability of change and the need to change their perceptions constantly (cf. Britzman, 2007).

Teachers see themselves as being under constant external pressure because they believe that parents and the general public do not understand the profound content and specificity of their activities, that is, teaching is not regarded as a professional activity - all views of teaching are presented and treated equally in public opinion. At the same time, the requirements for professional standards for teachers are very high (Kutsestandard ... 2005, 2013). In addition, in liberal societies, educational policy is in constant flux. It is therefore expected that the teacher will be able to respond to all conditions and adapt to different changes. These requirements also shape the teacher's self-image - they well perceive in what areas they'll need further additional training. With this background of such high demands, they have, inter alia, to set high standards and requirements for in-service education, which often does not meet expectations and is disappointing. So, teachers understand the importance of professional development and learning, but often do not receive professional support applicable to their needs. Supporting colleagues, continuously (re)interpreting the content of their work and improving teaching activities, and positive feedback from learners will help teachers overcome frustration and tension. At the same time, coping with strain of change should not be the responsibility of the teachers themselves and their closest colleagues. Teachers need more relevant continuing education and counselling, and this poses challenges for educational institutions and universities preparing and supporting teachers (cf. Beck, 2005).

Much of the stress in teacher's work is not directly caused by the teacher's own actions or inaction, but only reflects the condition and development of society. Teachers probably need more support to enable them to understand and to give meaning to the changes in social backgrounds. A better supportive system that puts into focus a learners as well as a teacher, but acknowledging that teachers work inevitably in an ever changing environment and with different learners, would help to reduce tensions. In order to cope with changes and differences at the senior professional level, they need both constant, systematic, competent support and the activities of a professional teacher and 
decision making in teaching should trusted, and assume that the teacher sees the whole context of learning and works best in the given context.

Analysing the results of this study revealed, among other things, that the learning experience reflecting the social changes of teachers did not differ significantly by their age and subject areas. The results described can be regarded as generally characteristic of the teaching community in Estonia. At the same time, there are limitations to this generalization - we did not study the experiences of Russian speaking teachers, and this is a research methodology that does not show clear statistical relationships but describes the situation and highlights the experiences of teachers and their perceived meanings. Thus, in designing initial teacher training, in-service education as a support system, teachers' needs in terms of support for professional development and the overcoming of tension should be examined more.

Keywords: educational change, neoliberalism, social learning, teacher 